\title{
Do climate changes influence dispersal and population dynamics of dragonflies in the western Peruvian Andes?
}

\author{
Joachim Hoffmann \\ Alauda, Wendenstr. 435, D-20537 Hamburg, Germany \\ Corresponding author: Joachim Hoffmann (hoffmann.joa@t-online.de) \\ Academic editor: Jürgen Ott | Received 28 July 2010 | Accepted 18 August 2010 | Published 30 December 2010 \\ Citation: Hoffmann J (2010) Do climate changes influence dispersal and population dynamics of dragonflies in the \\ western Peruvian Andes? In: Ott J (Ed) (2010) Monitoring Climatic Change With Dragonflies. BioRisk 5: 47-72. doi: \\ 10.3897/biorisk.5.842
}

\begin{abstract}
For nine dragonfly species (five aeshnids and four libellulids) all previous and verifiable data are related to the vertical climate zones and nature regions of the western Peruvian Andes and the Peruvian Pacific coast. Climate changes due to the El Niño and La Niña phenomena, as well as the global climate change have an influence on the different natural regions and also restrict aquatic biotopes. These changes influence the dispersal and behavior of some dragonflies and concern also loss of habitats as well as alterations of biotic and abiotic factors at and in water.

However new waters and habitats also are formed in most nature regions. Specialists like Rhionaeschna peralta, a species of high mountain regions and the Puna, are not able to react to habitat losses by adaptation, while other species such as $R$. maita and $R$. marchali do colonize new habitats also in higher altitudes. While the here represented aeshnids change their distribution ranges within the vertical nature regions of the west Andes, this is suspected for three of the four libellulids (Orthemis ferruginea, O. discolor and Pantala flavescens) as latitudinally respectively longitudinally immigrations and expansions of their areals.

For all species discussed, a seasonally earlier flight beginning is detectable, but for no species an extension of their flight time.

Altogether, the above named three libellulid do react more flexibly and faster to the alterations by climate changes than the majority of the five aeshnid species.

The influence of increased UV-B and UV-A radiation possibly affects also the site occurrence of some species in high altitudes of the Andes.
\end{abstract}

Copyright Joachim Hoffmann. This is an open access article distributed under the terms of the Creative Commons Attribution License, which permits unrestricted use, distribution, and reproduction in any medium, provided the original author and source are credited. 


\section{Keywords}

climate changes, dragonflies, effects, biodiversity, biogeography, Peru, Andes

\section{Introduction}

Until a few years ago, climatology was in Peru exclusively limited to examinations of the El Niño events and the consequences for agriculture and fishery. With signing the Kyoto Protocol measurements and supervision of the $\mathrm{CO}_{2}$-emmissions were also included as part of the responsibility (SENAMHI 2006). In 1994 the national environmental council CONAM (Consejo Nacional del Ambiente) was brought into being (Congreso de la República 1994), which in 2001 with the submission of the first report to the UN also fixed the subject of climate change as the main focus of its work (CONAM 2001). It was not until 2003 that studies of the effects of climate changes on the biodiversity were incorporated in the conceptual formulations (CONAM 2004) - though the term "biodiversity" referred exclusively to cultivated plants and economically useful animal species.

To the present day there are only a few studies to the biodiversity of the western Peruvian Andes, and these concern botanical recordings and research on a few zoological taxa such as mammals, birds and butterflies which allow some statements to species diversity. Within the scope of such investigations by North American and Peruvian biologists since the beginning of the 90s of the last century, Odonata were also increasingly collected and deposited with the Natural History Museum (Museo de Historia Natural de la Universidad San Marcos) in Lima. Wider samplings in the coastal regions to 1400 - $\mathrm{m}$ height and the high andean ranges between 3000 and $5000 \mathrm{~ms}$ were carried out since 1989 in irregular intervals by the author (Hoffmann 1991, in prep). However these investigations are up to now limited, however, to a pure sampling activity without studies to Odonata coenosis and its ecology. These data and also the odonatological collections of the Natural History Museum in Lima, the University La Molina in Lima and the University of Cajamarca reveal for some species of the suborder Anisoptera changes in the dispersal behavior which is possibly caused of climatic changes within their distribution ranges.

Out of 481 dragonflies recorded in Peru (Hoffmann 2009), 46 species were sampled up to the present in the western Andes and the coastal desert. Some species from the families Aeshnidae and Libellulidae should be looked at more closely here, because at least enough data are available to be able to discuss changes due to climate change. 


\section{Definition and data}

\section{Ecological Regions}

According to different authors, the division of the Andes into ecological regions is variably handled. For example Brack (1985) distinguishes four terrestrial ecological regions in the West Andes and coast. The Instituto Nacional de Geografía de Peru defines for the same area of Peru five regions (INGP 1989) and later with 14 subregions (in INRENA 1995). All three works are primarily based on precipitation and temperature data as well as plant communities. However, the subdivision into partly very small-flat subregions (exclusively guided by plant communities) is at least not partially when viewed objectively comprehensible.

A first division of the Peruvian Andes into nature regions was undertaken by Pulgar Vidal (1967) and was revised completely in the ninth edition in 1987. Pulgar Vidal divides Peru primarily in nature regions in accordance with:

- altitudinale zones

- relief

- climate

- vegetation

- fauna

- agriculture

- (historic) folklore

The nomenclature adapts the Indian population's original Quechua-names. The division of the West Andes (incl. coast desert) takes place accordingly in six regions (Table 1 and Fig. 1).

\section{Climate and Weather Records}

Generally the nature regions, as well as the ecological regions of the Peruvian West Andes are according to Pulgar Vidal (1987) and Brack (2000) related to climate gradients,

Table I. Relation of natural areas in the westerns Andes to altitudinal zones

\begin{tabular}{l|r}
\hline nature regions & altitudinal zones \\
\hline Chala („,coast“) & $0-500 \mathrm{~m}$ \\
\hline Yunga („temperate valleys“) & $500-2.300 \mathrm{~m}$ \\
\hline Quechua („Farm land“) & $2.300-3.500 \mathrm{~m}$ \\
\hline Suni („narrow plain“) & $3.500-4.000 \mathrm{~m}$ \\
\hline Puna („uninhabitable heights“) & $4.000-4.800 \mathrm{~m}$ \\
\hline Janca (,ice land“) & $4.800-6.768 \mathrm{~m}$ \\
\hline
\end{tabular}




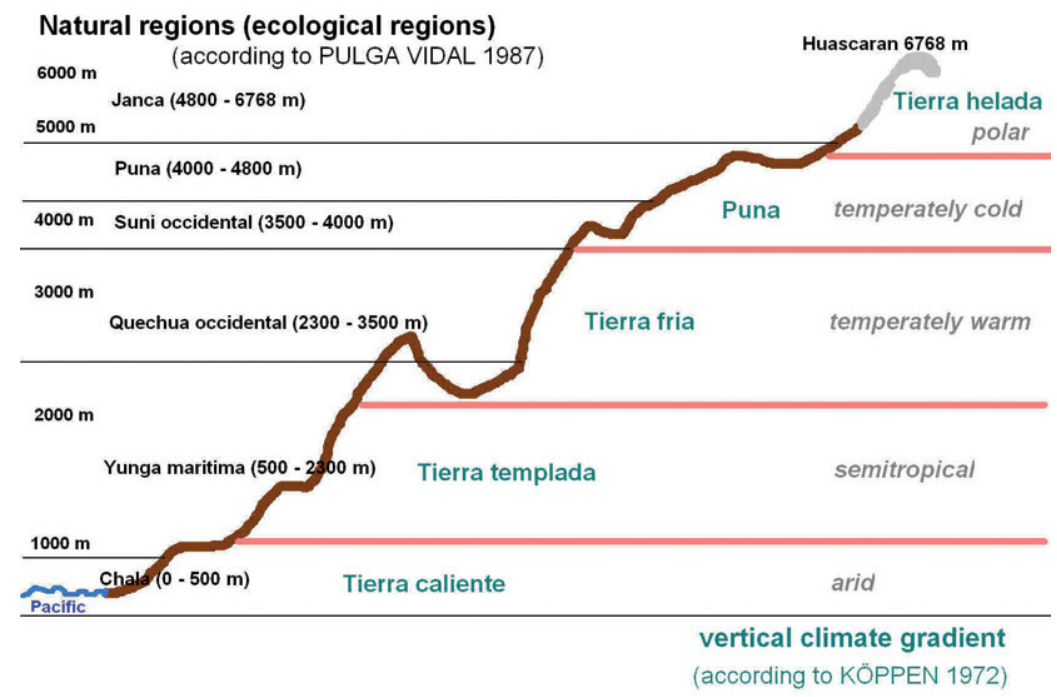

Figure I. Schematized profiles of the westerns Andes with its natural areas and vertical climate gradients

as they are also applied to the vertical zonations of altitude zones of mountains (Fig. 1) according to the climate zonation by Köppen 1972 .

Temperature decreases with rising altitude, the precipitations increase at first and then decrease also with sinking temperatures. This is very similar to the meridional course of the values of these climate elements in direction towards the pole (Table 2).

Long-term weather records in Peru before are only from few places and generally as from the 1980er years. Secular data series are only available from Lima.

The peculiarity of the mainland climate in the western part of the Andes is dictated by the Humboldt Current and El Niño events. The absence of the cold Humboldt Current is created by the El Niño event, which in turn causes a "natural" climate alteration of irregular intervals about Christmas time for several weeks occasionally. This ENSO-mechanism (El Niño / Southern Oscillation) stands in competition to the anthropogenic "greenhouse effect" (Arntz and Fahrbach 1991; Schönwiese 1995).

The El Niño event has the effect of producing hard showers in the coastal belt up to an altitude of $2.500 \mathrm{~m}$ (Quechua), while temperatures and precipitations at greater heights are influenced more weakly.

\section{Meteorological data}

It is very difficult to obtain weather records in Peru. The National Meteorological Institute (SENHAMI) functions under the auspices of the ministry of defense and weather data are provided only under certain prerequisites and then only against very high fees. Furthermore long-term series of measurements exist only from a few places. These are often interrupted for longer periods of time due to faulty measuring instruments. 
Table 2. Relation of natural areas in the westerns Andes to altitudinal zones, precipitation and temperatures

\begin{tabular}{l|r|r|r}
\hline nature regions & altitudinal zone & $\begin{array}{r}\text { annual mean } \\
\text { of percipitation }\end{array}$ & $\begin{array}{r}\text { annual mean } \\
\text { of temperature }\end{array}$ \\
\hline Chala & $0-500 \mathrm{~m}$ & $90 \mathrm{~mm}$ & $20^{\circ} \mathrm{C}$ \\
\hline Yunga & $500-2.300 \mathrm{~m}$ & $170 \mathrm{~mm}$ & $19^{\circ} \mathrm{C}$ \\
\hline Quechua & $2.300-3.500 \mathrm{~m}$ & $500-1.000 \mathrm{~mm}$ & $12^{\circ} \mathrm{C}$ \\
\hline Suni & $3.500-4.000 \mathrm{~m}$ & $700-1.300 \mathrm{~mm}$ & $10^{\circ} \mathrm{C}$ \\
\hline Puna & $4.000-4.800 \mathrm{~m}$ & $1.000 \mathrm{~mm}$ & $6^{\circ} \mathrm{C}$ \\
\hline Janca & $4.800-6.768 \mathrm{~m}$ & $700 \mathrm{~mm}$ & $1^{\circ} \mathrm{C}$ \\
\hline
\end{tabular}

The data used here were gathered predominantly from publications of SENHAMI, Internet presences and series of measurements by mining companies in the Andes. Older data were partly published in the "Atlas Del Peru" (Inst. Geogr. Nac. 1989). Rare weather informations which are also taken into account can be found in older odonatological publications (e.g. Calvert 1956).

With the beginning of the CCA project in Peru (Hoffmann 2006) diurnal data at the sample waters were recorded by a mobile weather station ${ }^{1}$. These however always represent only at hourly intervals values at a research locality for the duration of the stay. In addition to the weather data, the UV radiation (UV-A and UV-B) was also included.

\section{Hydrological data}

In 2006 all waters examined were analysed (abiotic factors), conductivity, $\mathrm{pH}$, water hardness, temperature and oxygen content being measured. Unfortunately, the device for measuring oxygen already ceased functioning at the beginning of the examinations. For future measurments water level gauges were installed at the waters.

Water temperatures of some larger waters were often taken in the course of hydro geological examinations (e.g. CONAM 2005) and were taken from relevant publications. Other sources are found in publications of Peruvian limnologist and also among mine companies which from time to time measure water-levels of large lakes. Such data were provided by the national park office Huascaran.

\section{Dragonfly data}

In the present consideration literature data (Calvert 1956, Schmidt 1952, Ellenrieder 2003 and others) was used although only a very few publications take into account the odonata fauna of the western Peruvian Andes. The verification of localities proved

1 The weather station were entrusted to the administration of the National Park Huascaran and remained for the purpose of long-term series of measurement at Pampacocha, a lake in the Puna (4,068 m of height). 
to be very difficult. The description of species and the publication of species lists as a rule were not made by the collectors themselves or by scientists on the spot, but by odonatologists in Europe or the USA. Locality labels in many cases have been assigned, interpreted or read wrongly ${ }^{2}$. Records which could not be verified were not taken into consideration.

Data from the entomological collections of the universities of Cajamarca and La Molina (Lima), as well as the Natural History's museum in Lima formed an essential basis. These however required a thorough revision since more than $30 \%$ of the specimen from the western Andes had been wrongly identified. Since 1994 Günther Peters (Berlin) thankfully accepted the examination of the aeshnids.

Furthermore, since 1989 the author regularly collected in the Peruvian western Andes, predominantly in the departments of Ica, Lima and Ancash (Hoffmann 1991 and in prep). Current data on odonata exist from the "Climate Change and Aeshnids - Project" in January and February 2006, August and September 2006 as well as February and March 2007 (CCA, Hoffmann 2006).

\section{Results}

\section{Climate}

Since there is a historically natural influence on climate by the ENSO mechanism (El Niño / Southern Oscillation), this phenomenon will first be described.

\section{El Nińo / La Nińa}

As an "El Niño" is called the appearance of an unusual, non-cyclic, change of currents in the oceanographic-meteorological system of the equatorial Pacific.

When it occurs, the cold Humboldt Current decreases along the Chilean and Peruvian coast until it succumbs. This happens due to a shift of the wind zones through which the normal west flow of near-surface (warm) sea water flows back to the east. The Walker-circulation has reversed itself, with the consequence that the east Pacific heats up. Its roll in the global warming heating is discussed controversially. While

2 For example: for $R$. elsia is given by Calvert (1956) and later by Ellenrieder (2003; assumed from Calvert) a locality "Huanuco". Today this place (see distribution map in Ellenrieder) is the capital of the same named department in the eastern slope of the Andes at a height of barely 2000 m. An unusual locality for a strong "coastal dragonfly", which only occurs on the west side of the Andes. It must be assumed that there is a mistake in the later localization. Thus there is a small place called Huanaco on the coast in the department of Ancash and in the department of Arequipa likewise near to the coast a place called Huancan. From both places are collection records of $R$. elsia, as well as of other species. 
el Niño is a natural climate phenomenon it is, nevertheless, supposed that it will be strengthened by the anthropogenic greenhouse effect.

A current study points out, that El Niño events, particularly big ones, can be predicted more exactly than was previously assumed (Chen et al. 2004).

La Niña is an extremely cold current in the equatorial Pacific in contrast to El Niño, the naming being based on what, so to speak, is an anti-El Niño.

La Niña usually follows an El Niño event being triggered by exceptionally high differences of atmospheric pressure between South America and Indonesia. This leads to stronger trade winds. The warm water is driven at the surface in the Pacific Ocean by the trade wind to South-East Asia. As a result cold water flows up from the depth of the Pacific on the coast of Peru. This upwelling water lies up to $3^{\circ} \mathrm{C}$ below the average temperature.

The consequences are not as strong as in the case of the El Niño, but La Niña nevertheless has a considerable influence:

- $\quad$ in the west Pacific the water at the surface is warmer,

- $\quad$ in South-East Asia La Niña brings rains and colder temperatures,

- $\quad$ in South America it rains less and the deserts dry up.

Altogether, less natural disasters occur, however, than during an El Niño.

The number of La Niña events has decreased during the last decades, that of the El Niño events has increased (fig. 2). The assumption exsists that the anthropogenic greenhouse effect is responsible for this situation. Up to now, this could however not be proved.

According to the data of the last 66 El Niño events, those of 1925, 1933, 1941, 1957,1972 , 1982-1983 and of 1997-1998 were the strongest and a group of ten (1932, 1939, 1943, 1953, 1965, 1987 and 1990-1995, additionally 2001, 2004 and 2006-2007) are estimated as moderate to weak (acc. to Woodman-Pollit 1998).

An El Niño event lasts for about twelve to eighteen months and has its acme between December and June. Indeed, there were - dependent on definition - two recent exceptions: one event lasted from the middle of 1990 to the middle of 1995 while the Niño of $1997 / 98$ was clearly shorter (NOAA 2005).

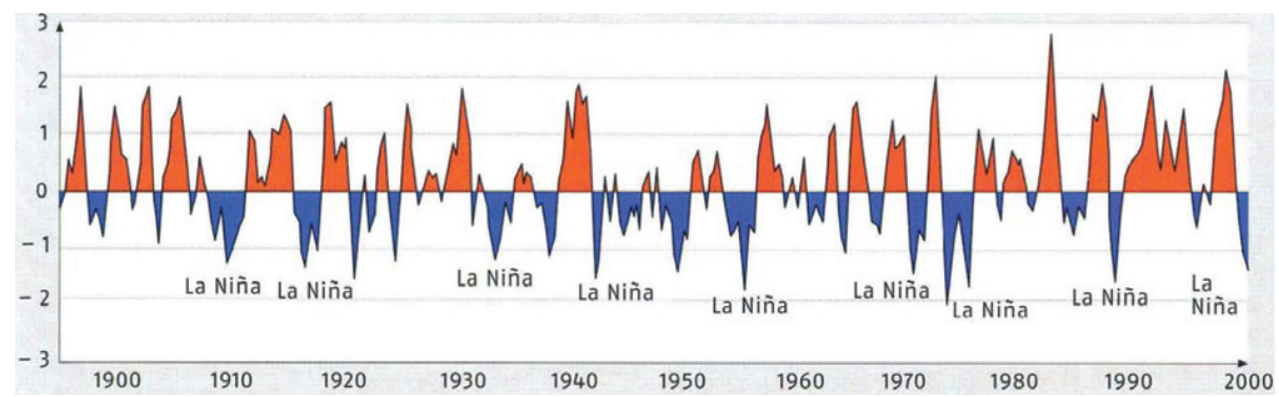

Figure 2. Sequence of El-Niño-and La Niña episodes in $1890-2000$; temperature deviations $\left({ }^{\circ} \mathrm{C}\right)$ are shown (acc. to Caviedes 2001) 
An El Niño influences the weather predominantly on the coast up to the upper Yunga, has however, also an influence up to the uppermost elevated regions of the western Andes. Changes can only be perceived and measured during the events, but also influence the climate before and after event, though only to a slight degree. For example the El Niño event from November 1997 to April 1998 caused in Pisco (Pacific coast) maximal precipitations of $212 \mathrm{~mm}$ in December, while in January the amount of precipitation sank to $38.7 \mathrm{~mm}$. On the other hand, the amount of precipitation in the Chala lay at about the level of the previous years while in the Puna however it lay under those of previous years (fig. 6). In May 1998 the amounts of precipitation lay in Pisco with $12 \mathrm{~mm}$ again in the range of the long-term averages.

Effects on the temperature development in El Niño years are noticeable up to the high regions (s. fig. 5, year 1998).

\section{Climate changes}

According to Hanson et al. (2006) the measured temperatures have increased in the annual global mean temperature since 1970 to 2005 by $0.6^{\circ} \mathrm{C}$ (fig. 3).

The increase in the global annual means of measured temperatures since 1985 till 2005 amounts altogether $0.5^{\circ} \mathrm{C}$. This corresponds in the five-year means since 1990: $1990-1995=0,1^{\circ} \mathrm{C}, 1995-2000=0,2^{\circ} \mathrm{C}$ and $2000-2005=0,3^{\circ} \mathrm{C}$.

The increase of the measured temperatures from 1985 to 2005 amounted to a maximum of $0.8^{\circ} \mathrm{C}$ in the western Andes (Puna) and a minimum of $0.2^{\circ} \mathrm{C}$ (Chala). With respect to all altitudes of the Peruvian western Andes the temperature increase since 1985 probably lies between $0.5^{\circ} \mathrm{C}$ and $0.8^{\circ} \mathrm{C}$ (no meteorological data are available from Yunga, Suni and Jalca). An increase twice as high as the global mean. The last five-years showed in 2000-2005 a smaller increase in the Puna and a slight decline in the Chala (fig. 4).

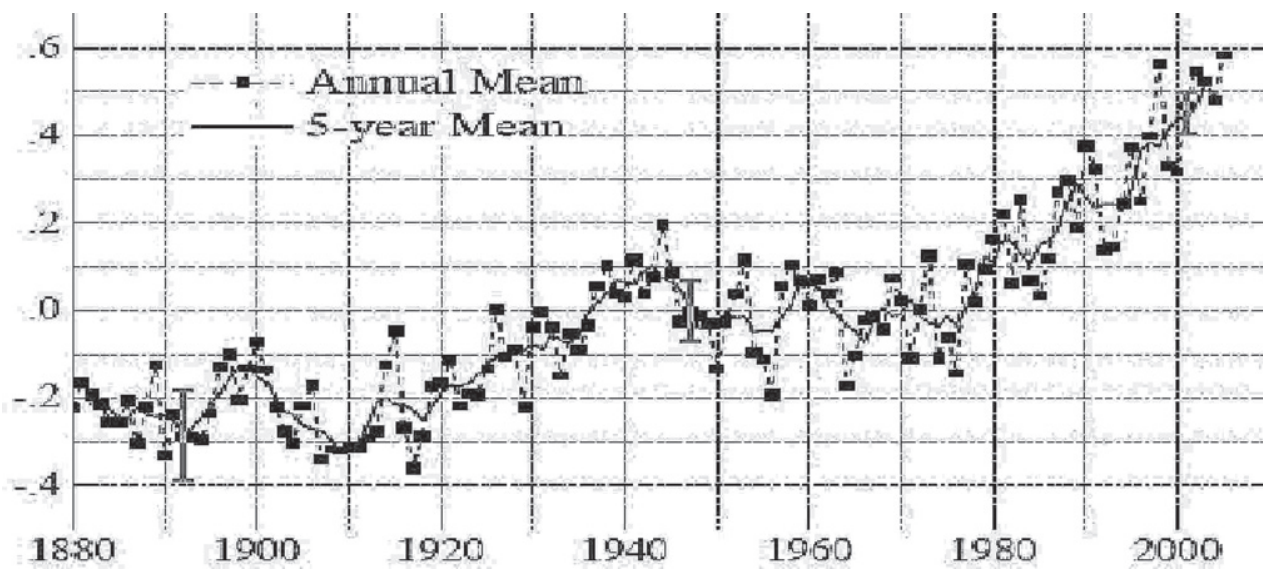

Figure 3. Global mean surface temperature anomaly $\left({ }^{\circ} \mathrm{C}\right)$. Global annual surface temperature relative to 1951-1980 mean based on surface air measurements at meteorological station and ship and satellite measurements for sea surface temperature (from Hanson et al. 2006). 


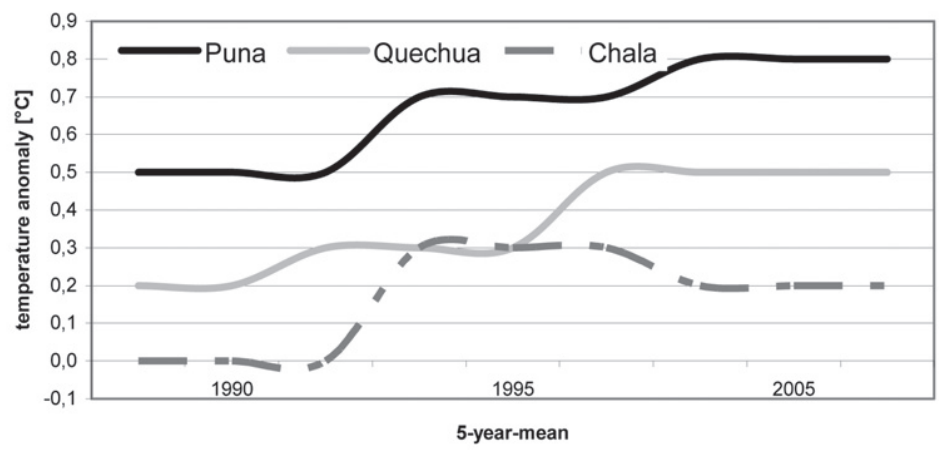

Figure 4. Altitudes-mean temperature anomaly $\left({ }^{\circ} \mathrm{C}\right)$ in the nature regions Puna $(4,000 \mathrm{~m})$, Quechua $(3,050 \mathrm{~m})$ and Chala $(60 \mathrm{~m})$. Annual temperature mean based on surface air measurements at meteorological stations (source: SENAMHI 2006).

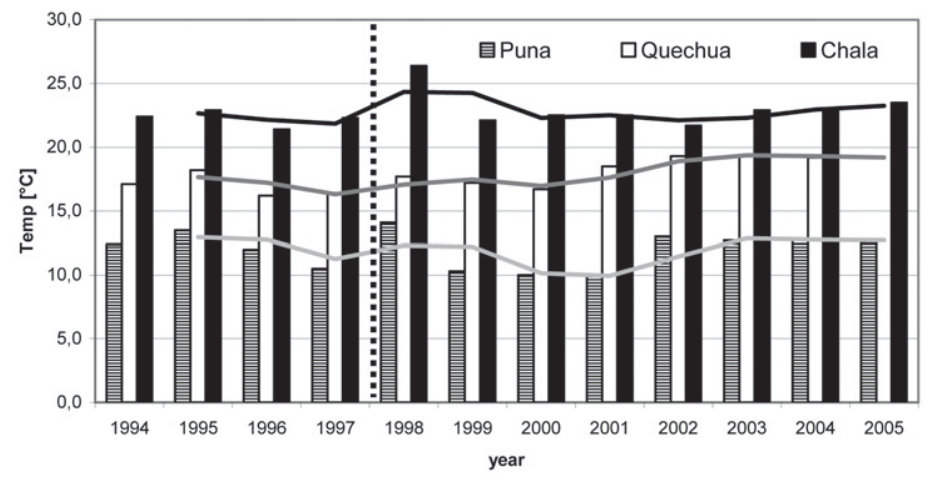

Figure 5. Average January temperatures in Puna $(4,000 \mathrm{~m})$, Quechua $(3,050 \mathrm{~m})$ and Chala $(60 \mathrm{~m})$ for a period of the past eleven years. Curves: gliding average for two periods; spotted line: occurrence of El Niño (source: SENAMHI 2006)

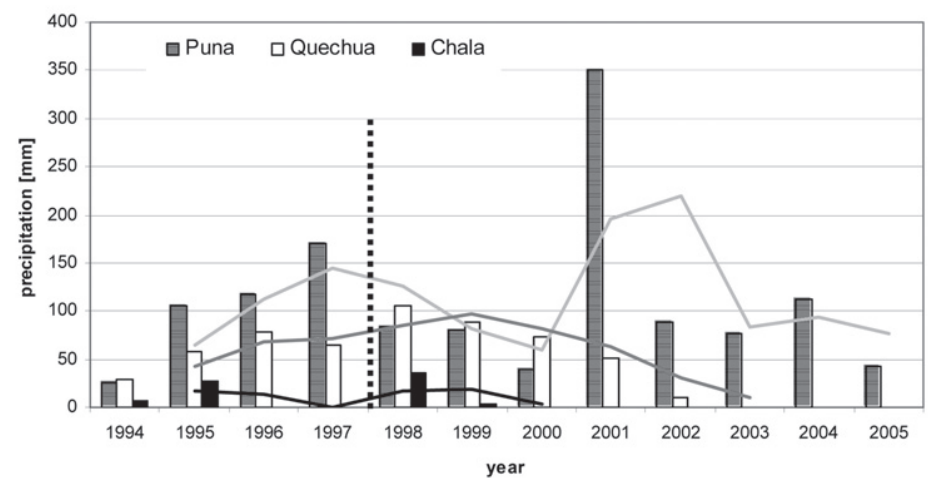

Figure 6. Average January precipitations in Puna $(4.000 \mathrm{~m})$, Quechua $(3.050 \mathrm{~m})$ and Chala $(60 \mathrm{~m})$ for a period of the past eleven years. Curves: gliding average for two periods; spotted line: occurrence of El Niño (source: SENAMHI 2006) 
The average temperatures for January (midsummer) since 1994 are marked by a slight increase in the Quechua and since 2000 also in Chala and Puna. The increase of the temperatures primarily in the Chala could have been caused by the El Niño event 1997/1998 (fig. 5). The decrease of temperatures of 1999 and 2001 were accompanied by a La Niña event within these years (cf. fig. 2).

The amount of precipitation decreased continuously in Chala and Quechua since 1997 / 1998. The amount in the Puna is very irregularly, with a not interpretable peak in the year 2001 (fig. 6).

The relative atmospheric humidity in January is relatively constant in the Chala with an increase of only $3 \%$ on average over the last eleven years. In the upper altitudes of the Puna a continuous decline of more than 20\% is remarkable, in the Quechua the values show great variations of up to $16 \%$ (Fig. 3-6).

\section{Dragonflies (Aeshnidae and Libellulidae)}

Interpretable data are available for the following species. It should be noted that Rhionaeschna maita is thought of as a good species in contrast to Ellenrieder (2003) who classified it as a synonym of $R$. brevifrons ${ }^{3}$ :

Aeshnidae

Rhionaeschna maita (Förster, 1909)

Rhionaeschna absoluta (Calvert, 1952)

Rhionaeschna elsia (Calvert, 1952)

Rhionaeschna marchali (Rambur, 1842)

Rhionaeschna peralta (Ris, 1918)

Libellulidae

Erythrodiplax cleopatra (Ris, 1911)

Orthemis ferruginea (Fabricius, 1775)

Orthemis discolour (Burmeister, 1839)

Pantala flavescens (Fabricius, 1798)

Two patterns (three time periods) were taken for the details on the phenology:

Records and information before 1956: Information from collections and literature; only of very few sources are available or collector activities must be estimated as very low.

3 Rhionaeschna maita is represented here as a good species because there are some significant differences to $R$. brevifrons. Possibly a "wrong" lectotype was synonymized by Ellenrieder (2003), then the actually published photos by Geller-Grimm (2005) of the putative holotype de facto show Rhionaeschna brevifrons and do not correspond to the first description of $R$. maita by Förster (1909). Both Ris (1913) and Schmidt (1952) describe $R$. maita as closely related to Rhionaeschna marchali, to which resembles in many characteristics. All three species are sympatric in the upper Yunga and the lower Suni. 


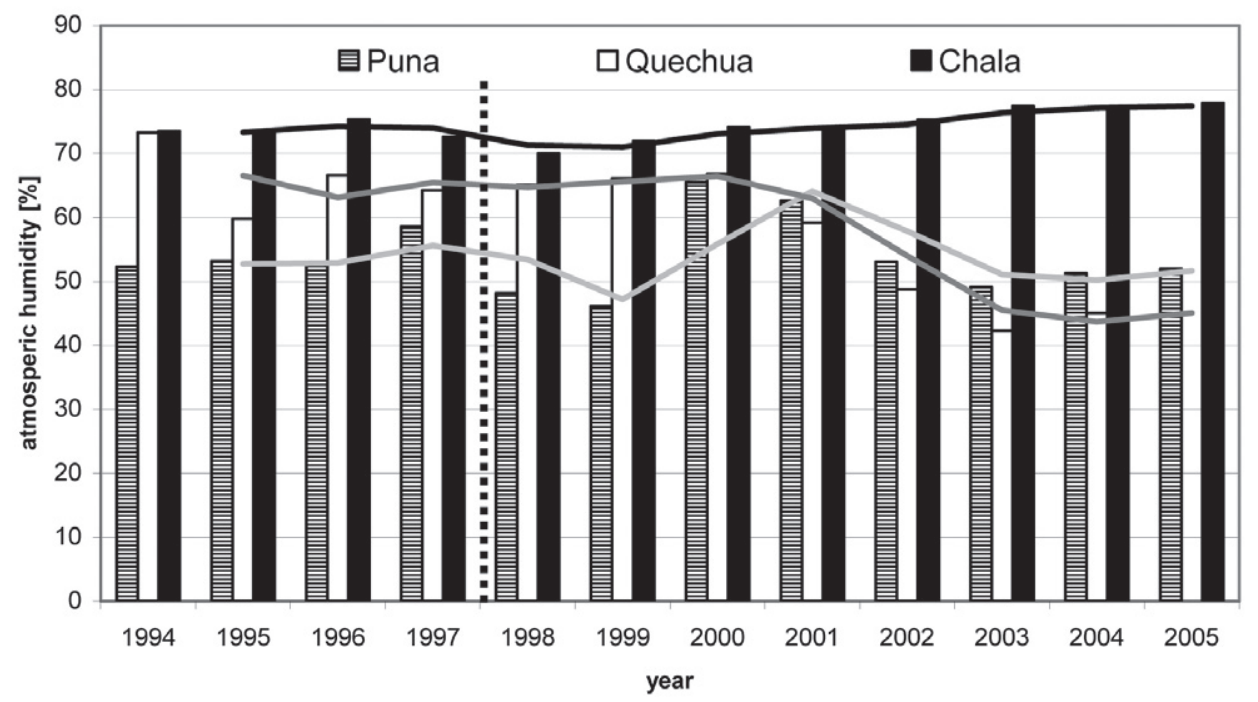

Figure 7. Average January atmospheric humidity in Puna (4,000 m), Quechua $(3,050 \mathrm{~m})$ and Chala (60 $\mathrm{m})$ over a period of the past eleven years. Curves: gliding average for two periods; spotted line: occurrence of El Niño (source: SENAMHI 2006)

Records and information before 1996: at least from 1982 to 1996 data were regularly collected in complete annual courses, also in the western Andes and the coastal region.

Records and information after 1996: samples in irregular time periods, with some years not sampled at all.

Current results from the CCA project begun in 2006 (Hoffmann 2006) are presented separately.

\section{Aeshnidae}

\section{Rhionaeschna maita (Förster, 1909)}

Nature region: Until 2005 the species was recorded exclusively in Quechua and Suni at altitudes between 2,300 $\mathrm{m}$ and 3,900 $\mathrm{m}$. Evidence is currently (2006) available from the Puna at 4,100 m. Some records from the Yunga and the lower Quechua must be ascribed to the sister species Rhionaeschna brevifrons on the basis of re-determinations of collection material.

Phenology: Obviously the flying time in the upper altitudes (more than 3,000 $\mathrm{m}$ ) is from August to October, i.e. in the "andean spring" while at less than 3,000 m a second flight period from February to May ("andean autumn") is found. 


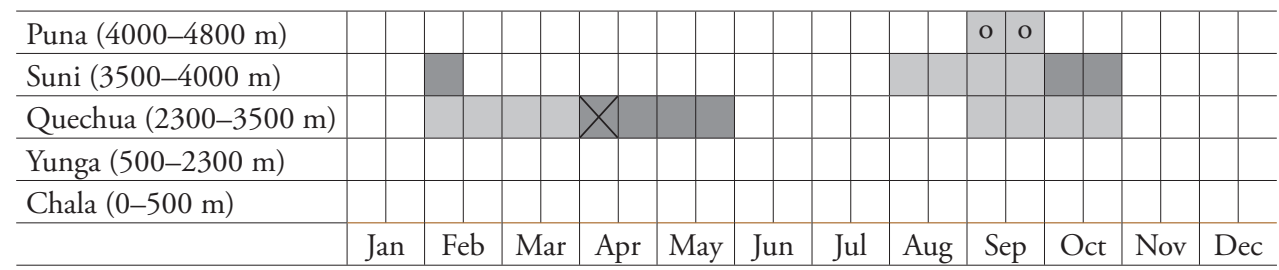

records before 1996 records after 1996

records before 1956 (Calvert 1956)
o migrating specimens

Habitat utilization: Till now the species was found only at mesotrophic, predominantly slow running and not too cold $\left(>15^{\circ} \mathrm{C}\right)$ waters.

\section{Rhionaeschna absoluta (Calvert, 1952)}

Nature region: The main distribution of $R$. absoluta is in Yunga and Quechua. As the only species of the genus Rhionaeschna it was recorded also from the eastern high Andes at $3,800 \mathrm{~m}$.

\begin{tabular}{|c|c|c|c|c|c|c|c|c|c|c|c|c|}
\hline Eastside of the Andes & X & & & & & & & & & & & \\
\hline Suni $(3500-4000 \mathrm{~m})$ & & & & & & & & & & & & \\
\hline Quechua (2300-3500 & & & & & & & & & & & & \\
\hline Yunga $(500-2300 \mathrm{~m})$ & & & & & & & & & & & & \\
\hline Chala $(0-500 \mathrm{~m})$ & & & & & & & & & & & & \\
\hline & Jan & Feb & Mar & Apr & May & Jun & Jul & Aug & Sep & Oct & Nov & Dec \\
\hline
\end{tabular}

records before 1996 records after 1996

Phenology: The species shows two flight periods which are similarly to those of $R$. maita in the "andean spring" and "andean autumn". Records from the Yunga in the months August to October are available only since 1999, but then regularly.

Habitat utilization: Except at strongly flowing waters $R$. absoluta was found at all other types of waters. Eutrophic waters are preferred, oligotrophic waters avoided.

\section{Rhionaeschna elsia (Calvert, 1952)}

Nature region: Until now this species was found only in the arid coastal area of Peru. All findings until 1996 are up to $500 \mathrm{~m}$ above sea-level. In 2001 R. elsia was found for the first time in the Yunga at $900 \mathrm{~m}$ and in 2006 even at $1500 \mathrm{~m}$.

Phenology: Obviously the flight times also have changed. Calvert (1956) indicates February to May as the period; later records (until 1996) cover a longer time from Oc- 


\begin{tabular}{l|l|l|l|l|l|l|l|l|l|l|l|l|l|l|l}
\hline Yunga $(500-2300 \mathrm{~m})$ & & & & & & & & & & & & \\
\hline Chala $(0-500 \mathrm{~m})$ & & &
\end{tabular}

records before 1996 records after 1996

records before 1956 (Calvert 1956)

tober to July and more recent records (1996 onwards) cover the period from the end of August till the middle of July, indicating a phenological omnipresence.

Habitat utilization: Former records were taken exclusively in standing, mostly brackish waters (coastal lagoons and ponds). The records from the Yunga (900 m respectively 1,500 $\mathrm{m})$ come from stagnant waters or temporary ponds in dry riverbeds. In 2006 imagos and larvae were also collected from a slowly flowing brook in the Chala at an altitude of $285 \mathrm{~m}$.

\section{Rhionaeschna marchali (Rambur, 1842)}

Nature region: The main distribution of the species is in Yunga and Quechua between $1,900 \mathrm{~m}$ and 2,900 m. Currently (2006) R. marchali was also stated from the Suni between $3,500 \mathrm{~m}$ to $3,800 \mathrm{~m}$. According to Calvert (1956) obviously the species also occurs on the eastern Andean slope. This, the only record from the 1930s could, however, not be verified.

\begin{tabular}{|c|c|c|c|c|c|c|c|c|c|c|c|c|}
\hline Suni $(3500-4000 \mathrm{~m})$ & & & & & & & & & & & & \\
\hline Quechua (2300-3500 & & & & & & & & & & & & \\
\hline Yunga $(500-2300 \mathrm{~m})$ & & & & & & & & & & $x$ & & \\
\hline Chala $(0-500 \mathrm{~m})$ & & & & & & & & & & & & \\
\hline & Jan & Feb & Mar & Apr & May & Jun & Jul & Aug & Sep & Oct & Nov & Dec \\
\hline
\end{tabular}

records before 1996 records after 1996

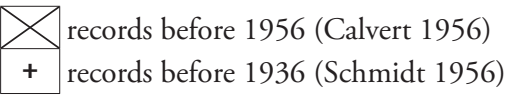

Phenology: In the Quechua the species flies all the year round, except for November and December, the flight records for May to July having been taken before 1956 . In Yunga and Suni the flight time is probably limited to the "andean spring".

Habitat utilization: Ellenrieder (2003) stated as habitats wet soils, crop pastures, muddy bottom pools, creeks, running brooks with aquatic plants and streams. Also according to current records (2006) the species occurs euryoeciously even in the Suni at $3,850 \mathrm{~m}$, where water temperature of all waters sampled was between $15^{\circ} \mathrm{C}$ and $23^{\circ} \mathrm{C}$.

\section{Rhionaeschna peralta (Ris, 1918)}

Nature region: A definite "mountain aeshnid" which occurs only above the Yunga $(2,300 \mathrm{~m})$ and which reproduces as the only aeshnid up to the lower margin of the 
Janca (records at 5,000 m; see Corbet 1999). The main distribution of the species in the Peruvian Andes lies in Quechua and Suni, i.e. between 2,300 ms and 4,000 ms.

Phenology: $R$. peralta is phenologically omnipresent at heights between $2,300 \mathrm{~m}$ to $4,300 \mathrm{~m}$ (similar to $R$. elsia on the coast).

\begin{tabular}{|c|c|c|c|c|c|c|c|c|c|c|c|c|c|}
\hline Janca (4800-6768 m) & & & & & & & & & & & & & \\
\hline Puna $(4000-4800 \mathrm{~m})$ & & & & & & & & & & & & & \\
\hline Suni $(3500-4000 \mathrm{~m})$ & & & & & & & & & & & & X & \\
\hline Quechua $(2300-3500 \mathrm{~m})$ & & & & & & & & & & & + & + & \\
\hline Yunga $(500-2300 \mathrm{~m})$ & & & & & & & & & & & & & \\
\hline Chala $(0-500 \mathrm{~m})$ & & & & & & & & & & & & & \\
\hline & Jan & Feb & Mar & Apr & May & Jun & Jul & Aug & Sep & Oct & & Tov & Dec \\
\hline
\end{tabular}

records before 1996

records after 1996

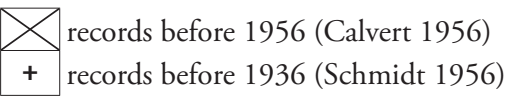

Habitat utilization: The species occurs at wide brooks, permanent stagnant waters as well as mesotrophical ponds in riverbeds in Quechua and Suni. Sampling localities in the Puna were lakes, bog ponds and flood areas of artesian springs. In the upper Puna and lower Janca $R$. peralta was also found at stagnant areas of open thermal springs (temperature of emerging water $35^{\circ} \mathrm{C}$, cooled down to $20^{\circ} \mathrm{C}$ at the outer edges). The temperatures of the water sample were between $16^{\circ} \mathrm{C}$ and $20^{\circ} \mathrm{C}$; all waters being mesotrophic to oligotrophic.

\section{Libellulidae}

\section{Erythrodiplax cleopatra (Ris, 1911)}

This species shows ecologically similar characteristics to Rhionaeschna elsia (see above).

Nature region: E. Cleopatra occurs mainly in the arid coastal area, however, ascends infrequently also to altitudes of $1,000 \mathrm{~m}$. Since 1996 records from more than $2,000 \mathrm{~m}$ are on the increase. Current records (2006) of E. cleopatra come from the lower Quechua at 2,500 m.

Phenology: In the Chala (arid coastal area) the species flies from October to May, i.e. with the exception of the winter month, for over eight months of the year. The

\begin{tabular}{l|l|l|l|l|l|l|l|l|l|l|l|l|l|l|l|l|l|l|l}
\hline Quechua $(2300-3500 \mathrm{~m})$ & & & & & & & & & & & & & & & & & & & \\
\hline Yunga $(500-2300 \mathrm{~m})$ & & & & ++++ & + & + & & & & & & \\
\hline Chala $(0-500 \mathrm{~m})$ &
\end{tabular}

records before 1996 records after 1996

\footnotetext{
$\triangle$ records before 1956 (Calvert 1956)

+ records before 1936 (Schmidt 1956)
} 
flight time at altitudes between $500 \mathrm{~m}$ to 2,500 m, i.e. in Yunga and Quechua, does not extend for more than five months, but beside this in August and September - in these months the species is missing in the Chala.

Habitat utilization: The majority of records in the area of the Chala and the lower Yunga is from stagnant waters and temporarily flooded ponds in riverbeds. In contrast to $R$. elsia, brackish waters with high salinity are obviously avoided. Current records from the upper Yunga at 2,000 m were taken exclusively from temporarily flooded ponds in riverbeds. In 2006 imagines and larvae were also obtained from a slowly flowing brook in the Chala at an altitude of $285 \mathrm{~m}$.

\section{Orthemis ferruginea (Fabricius, 1775)}

This species was recorded for the first time in Peru also as reproducing within the scope of the CCA project in the second half of September 2006, the sampling locality being situated in the Yunga at 1,200 m. The site was a mesotrophical, permanent pond in the bed of the Rio Santa.

\section{Orthemis discolour (Burmeister, 1839)}

The species has its main distribution in Peru to the east of the Andes.

Nature region: Most records from the western Andes are from the northern Chala up to $350 \mathrm{~m}$. There are a few records from the northern Yunga at $850 \mathrm{~m}$ and 1,900 $\mathrm{m}$. Currently $O$. discolor was sampled also in the lower Quechua at 2,500-m, far to the south of older record localities in the Yunga.

\begin{tabular}{|c|c|c|c|c|c|c|c|c|c|c|c|c|c|c|c|}
\hline Eastside of the Andes & & & & & & & & & & & & & & & \\
\hline Quechua $(2300-3500 \mathrm{~m})$ & & & & & & & & & & & & & & & \\
\hline Yunga $(500-2300 \mathrm{~m})$ & & & & & & & +1 & + & & & & & & & \\
\hline Chala $(0-500 \mathrm{~m})$ & & + & + & ++ & ++ & \begin{tabular}{l|l}
+ & + \\
\end{tabular} & & & & & & & & & \\
\hline & Jan & $\mathrm{Fe}$ & & $\mathrm{Ma}$ & & Apr & $\mathrm{Ma}$ & & Jun & Jul & Aug & Sep & Oct & Nov & Dec \\
\hline
\end{tabular}

records before $1996 \quad+$ records before 1936 (Schmidt 1956) records after 1996

Phenology: The flight time in the Chala extend for more than five months from the middle of October to the end of February. In the Yunga records are from May as well as from September and October after 1996. Currently (2006) the species was collected in September from the lower Quechua.

Habitat utilization: In the Chala $O$. discolor was recorded exclusively at mesotrophical to slightly eurotrophical standing waters, brackish coastal lagoons being avoided. The locations in the Yunga are mesotrophical standing waters in river beds 
and backwaters. The records in the Quechua were taken at an oligotrophical to mesotrophical backwater in the upper reaches of a brook.

\section{Pantala flavescens (Fabricius, 1798)}

Nature region: West of the Andes the species is autochthonous only in the Chala up to $500 \mathrm{~m}$. Nevertheless there were some records also from other nature regions above 4,000 m which before 1996 supported exclusively migrating specimens. Currently (2006) the species was sampled in the Yunga as well as in Quechua up to 2,800 m, in the Yunga already in 1999 autochthonous.

Phenology: The species flies in the Chala (arid coastal area) from October to May, i.e. with the exception of the peruvian winter about eight months of the year. Up to

\begin{tabular}{|c|c|c|c|c|c|c|c|c|c|c|c|c|c|}
\hline Puna (4000-4800) & & & & & & & & & & & & o & \\
\hline Suni $(3500-4000 \mathrm{~m})$ & & & & & & & & & & & & & \\
\hline Quechua $(2300-3500 \mathrm{~m})$ & & & & & & & & & & & & 0 & \\
\hline Yunga $(500-2300 \mathrm{~m})$ & & & & & & & & & & & & & \\
\hline Chala $(0-500 \mathrm{~m})$ & & ++ & + & + & & ++ & & & & & & & \\
\hline & Jan & Feb & $\mathrm{M}$ & & Apr & May & Jun & Jul & Aug & Sep & Oct & Nov & Dec \\
\hline
\end{tabular}

reco records before 1996 records after 1996

o migrating specimens

+ records before 1936 (Schmidt 1956)

now records in the Yunga are only for November and December. In the Quechua $P$. flavescens was found exclusively in August and September (including reproductive records), i.e. at a time when the species does not fly in its main distribution area western of the Andes.

Habitat utilization: In the arid coastal area $P$. flavescens is euryoecious and only avoids brackish waters with a high salinity and strongly running waters. A mass emergence in a swimming pool with several thousand specimens was stated from Tacna in February 1994 (Hoffmann 1998). In Yunga and Quechua the species could be found in mesotrophical ditches and temporary areas of standing waters in river beds.

\section{Discussion and conclusions}

\section{Climate change and abiotic sequence effects}

In what way global warming and the consequences of El Niño events overlap or mutually increase each other is not clear up to the present. It is noticable at least that the intervals between El Niño years become increasingly shorter, while the number of the Niña events is decreasing. Since the variations of the SST (sea surface temperature) have increased in the tropical Pacific during the last 100 years, and an accumulation 
of El Niño events appeared, the question is whether a connection exists between El Niños and the anthropogenically caused greenhouse effect. In order to find this out, Timmermann et al. (1998) have calculated and analysed a greenhouse simulation with a globally coupled ocean atmosphere model. It turned out that the eastern Pacific will warm up until 2100 by about $3^{\circ} \mathrm{C}$. On the other hand the west Pacific will warm up by only about $1^{\circ} \mathrm{C}$. This would mean that in future, situations similar to El Niño would much more frequently appear if the emission of greenhouse gases (primarily of $\mathrm{CO}_{2}$ ) is not limited or becomes reduced. Increasing interannuale variability overlaie the longterm warming trend.

Consequences of intensive El Niño events in Chala and Yunga (0-2,300 m) are documented adequately by state authorities in Peru, because these regularly impair the economy immediately and at short notice, particularly as far as the fishing industry and agriculture are concerned. Such documentations do not exist for the higher altitudes of the western Andes, possibly because the consequences do not play an important part here.

The climatic change due to global warming manifests itself much more strongly, although in El Niño years the change is hardly recognizable at the lower altitudes. Documentations of the consequences of the climate change are available only with regards to the melting of andean glaciers. The consequences although already recognizable and measurable, are shown merely as sequence scenarios.

In the mid 2006, a French-Peruvian project was started to now examine more intensely factors, progress and consequences of the gradual disappearance of the glaciers.

Analyses of satellite photos show for the Cordillera Blanca only, the largest tropical glacier massif, a reduction of the ice masses of $15 \%$ (corresponding to $13.5 \mathrm{~km}^{3}$ ) in the period 1970 to 1997 (27 years). During the last 35 years before 2005 (1970 to 2005) the reduction had accelerated and now, lies by 22\% (CONAM 2005), an increasement of $7 \%$ during eight years. In subareas such as the Huascaran massif, this decline amounted even to just below 30\% (CONAM 2001). According to UNESCO (2006) some smaller glaciers below a height of 5,000 m have already completely disappeared and others will be completely gone the latest by 2010 .

The melting of the glaciers in parts of the upper nature regions from 3,000 $\mathrm{m}$ to 4,800 m (upper Quechua, Suni and Puna) has at first sight provided a greater available of surface water, however, on the other hand, also a loss of the water reservoir of $12 \%$ compared to present day.

The melt water are led away by the rivers to the Pacific, with the result that these show from May to September higher water levels in downstream regions, also during the dry times in the Andes, where 20 years ago these rivers still fell dry at this time of the year.

At the same time, the amount of precipitation and atmospheric humidity decrease continuously from $500 \mathrm{~m}$ to $4,000 \mathrm{~m}$ altitude, while on the long term in all nature regions a rise in temperature is to be registered.

Beck et al. (2006) indicate changes in the extend of the climate zones defined by Köppen as a consequence of climatic warming. Thus positive trends are to be noted in 
South America for temperate climatic zones (average temperature of the coldest month between $3^{\circ} \mathrm{C}$ and $18^{\circ} \mathrm{C}$ ) and tropical climates (the coldest month less than $18^{\circ} \mathrm{C}$ ), while dry climates (no certain cycles nor summer nor winter rains) show a long-term decrease. Similar decreasing trends show the cold climates (average temperature of the warmest month below $\left.10^{\circ} \mathrm{C}\right)$.

\section{Habitat losses and formations of new habitats}

The climate changes cause in part considerable habitat losses both at upper altitudes and in the arid coastal zone.

Glaciers melting leads to more permanent wettings in the Puna as well as flooding of upland bogs as well as artesian and thermal springs.

Thus Rhionaeschna peralta could not be recorded any more at such waters and even disappeared from the highest up now recorded reproductive waters in the Jalca at 5,000 $\mathrm{m}$ (cf. Corbet 1999). Also at many Puna lakes the species was not found any more after 2001. The reasons for this could be a noticeable increase of the water-level which led (apart from an anthropogenic use) to the loss of the Totora reed (Scirpus sp. and Juncus sp.) as oviposition and larvae habitats. However, at other lakes in which the water levels have fallen during the last years due to the increased melting of the glaciers supplying them with water the abundances appears to have increased (e.g. Lake Titicaca).

A further reason for the disappearance of species is possibly also the increase in water temperatures of some lakes in the Puna (e.g. in the Cordillera Negra). Thus a surface temperature (at a depth of $20 \mathrm{~cm}$ ) of $21^{\circ} \mathrm{C}$ was measured in the Laguna Ututo (at 4,464 m) in 2006 (Hoffmann 2006). Here these waters were not or no longer fed by glacier waters. The centre of the distribution of $R$. peralta therefore lies at present between 2,300 $\mathrm{m}$ and 4,000 $\mathrm{m}$ in Quechua and Suni, in which the species apparently could profit in these regions from the formation of new habitats in form permantly water-bearing ponds and stagnant waters, for reasons of the steady melt water run-off in river beds profited, as long as these were mesotrophical.

For Rhionaeshna maita, with regard to the vertical distribution, the same applies as for $R$. peralta, with respect to their center of distribution in Quechua and Suni. While the latter appears to retreat, however, slowly from the Puna (see above), $R$. maita conquers at present waters in the lower altitudes of this region (up to 4,100 m). Apart from slowly flowing and mesotrophic run-offs of backwaters are preferred. As a rule, the temperatures of these waters do not lie below $15^{\circ} \mathrm{C}$. Such waters appeared within the last few $10-15$ years. The species thus occupies a newly arisen niche, which $R$. peralta due to its ecological claims - up to now it has never been recorded from running waters in the Puna - obviously cannot taken up. With increasing warming and as long as a water surplus will be available, $R$. maita will possibly ascent to higher altitudes in future. 
A further aeshnid which appears to profit from climatic changes is Rhionaeschna marchali. It has expanded its area of distribution from the Yunga and Quechua into the Suni and appears likewise to be euryoecious. Conspicuous for this species are mass appearences of the population, above all at standing waters in the Quechua, something that can possibly be explained due to increasing water temperatures (see below).

Similar trends in vertical distribution can also be ascertained in arid coastal region. Both Rhionaeschna elsia and Erythrodiplax cleopatra have extended their distribution into higher natural regions with $R$. elsia up to the middle Yunga at 1,500 $\mathrm{m}$ and E. cleopatra even up to the lower Quechua at 2,500 m. Both coastal species appear to profit from changed conditions, particularly with respect to suitable new habitats in the higher regions. On the other hand it is remarkable, that in particular $R$. elsia is no longer present at some coastal lagoons, but has recently appeared in slow running waters. Obviously the occurrence of this species is tied to the existence of slightly ionized waters (salts, conductivity values between $1.5 \mathrm{~S} / \mathrm{m}$ and 3.9 $\mathrm{S} / \mathrm{m}) 4$. Such condition of waters are at present increasingly full filled and areconverted into usable lands since particularly the need for agricultural products has increased and a permanent water regime of the rivers makes irrigation throughout the year possible as a result of the climate change. Furthermore it can be supposed that rising water temperatures and evaporation rates of the coastal lagoons also lead to habitat losses.

An example of a specie for which no changes in its vertical distribution can be ascertained is Rhionaeschna absoluta. The surprise is greater, because occuring exclusively in Yunga and Quechua- the species is considered as euryoecious and has been recorded up to now as the only species of the genus Rhionaeschna also in the eastern Andes.

\section{Changes of water temperatures}

Measurement series of the last 25 years of different types of waters prove a general increase of water temperatures of around up to $18 \%\left(\max .3 .6^{\circ} \mathrm{C}\right)$ in the nature regions above the Chala and even up to $27.5 \%\left(\max .9 .1^{\circ} \mathrm{C}\right)$ in a few small waters of the Chala. Some newly formed bodies of water by increased water effluents of the Quechua and Suni show temperatures of up to $25^{\circ} \mathrm{C}$. In very small coastal lagoons of the Chala up to $29^{\circ} \mathrm{C}$ were measured. No dragonflies could be found in such waters.

Some species, in particular aeshnids, give up waters in the upper altitudes with temperature rises of more than $21^{\circ} \mathrm{C}$. The only aeshnid which is an exception of this, and which appears to settle such waters is Rhionaeschna marchali.

On the other hand the majority of the species appears to profit from an increase in water temperatures in upper nature regions. Either they migrate due to changing conditions in their original reproduction waters to higher regions or they colonized new

4 For comparison purposes: seawater shows a conductivity of approx. $5 \mathrm{~S} / \mathrm{m}$, natural incidences of dissolved copper salts up to $5800 \mathrm{~S} / \mathrm{m}$ 
habitats without giving up their original waters in the lower regions, as for instance Orthemis discolor and Pantala flavescens.

\section{Phenological adaptation}

For the majority of the species discussed here, a change of flight times is noticeable after 1996, compared with former data. All species have flight times during the southern summer season with a beginning in "late spring". According to the altitudinal zone this beginning is "brought forward" during the last years at the end of the winters. Species which started to fly formerly only late in the seasonal course can already be found in spring (e.g. R. marchali in the Quechua and E. cleopatra in the Yunga). In connection with this it has to be pointed, that "winter" and "summer" - particularly with the exception of the Chala - have to be defined over the amounts of precipitation, dry and respectively rainy season. While temperatures rise above the Yunga in the longter mean, precipitations decrease over the same period of time (cf. fig. 5 and fig. 6). Other species such as $R$. elsia in the Chala and $R$. peralta between 2,300 $\mathrm{m}$ and 4,200 $\mathrm{m}$ (Quechua to Puna) fly recently over the whole year and are phenologically therefore omnipresent. Most species above 1,000 $\mathrm{m}$ are not flight-active against this during the months in June and July, with the lowest precipitations of the year. There was one exception, however in July 2006, in a really dry summer with precipitations of less than $5 \mathrm{~mm}$, already started in May (normally long-standing monthly means in May with $75 \mathrm{~mm}$ ). This resulted in a mass emergences of Rhionaeschna sp. in the Quechua, with thousands of dragonflies appearing in the streets of Huaraz $(3,048 \mathrm{~m})$ for several days. Inquiries through the local press and local inhabitants showed that it concerned without questions aeshnids, presumably Rhionaeschna marchali. Obviously there was a mass emergence briefly before with following migration events, similar to described in Europe for Hemianax ephippiger (Peters and Günther 2000; Günther 2005) and currently for Aeshna mixta (Günther 2006). As a cause it is to supposed that early beginning dryness and relatively high temperatures (monthly mean of daily temperatures of $27^{\circ} \mathrm{C}$ instead of $24^{\circ} \mathrm{C}$ of a long-standing mean) led to a drying up of standing waters with a low water-level. Because $R$. marchali starts to fly very early in the year (according to older data of Calvert 1956, the complete wintertime could not be confirmed until, however), it possibly concerned the phenomenon of an emergency emergence of the last larvae instar. Moreover the species flies at least in two generations.

Currently, changes in the phenology have become known for some European species, even if they probably still represent the exceptions (e.g. Sympetrum flaveolum, Kunz 2006).

On the other hand such "prolongations" of flight times as reported by BuschNowak (2002) about the very late emergence of Libellula depressa in October in BadenWurttemberg (Germany) and by Hoess (2006) about very late flight times of Coenagrion puella in Switzerland are not ascertainable from the western Peruvian Andes in an analogous way up to now. 


\section{Immigration}

Immigrations from distribution areas in distinct latitudinal climatic zones such as described by Ott (1996 and 2000) for Crocothemis erythrea are noticeable in the western Peruvian Andes at least for Orthemis ferruginea. Paulson (pers. comm. in Heckman 2006) considers Orthemis discolor as an own species and not conspecific to Orthemis ferruginea. He gives North and Central America as the distribution area of Orthemis ferruginea. Donnelly (1995) indicates that $O$. discolor has dispersed from South America along the Caribbean side to Florida whereas $O$. ferruginea coming from North America dispers along the pacific side to Costa Rica. Both species are sympatric in parts of Mexico and Costa Rica (fig. 8) and sometimes even occur at the same waters.

On checking the collection material from Peru, some years ago, it was discovered that all specimens (with one exception) determined as O. ferruginea, had to be reassigned to $O$. discolor. Merely a male from the northern Yunga collected in August 2001 belonged to $O$. ferruginea. Later an ovipositing couple was caught in September 2006 about $400 \mathrm{~km}$ south of the first location, also in the Yunga. Possibly the species is distributing along the Pacific coast in a southerly direction which means that it could also occur in Ecuador and Colombia. At present, the distribution of $O$. ferruginea still appears to be discontinuous.

Obviously the equatorial climatic zone extending for over $1,000 \mathrm{~km}$ from Costa Rica to Colombia has been up now a barrier which prevented dispersals to the south. Beck et al. (2006) show climatic changes in the pacific coastal areas, in that the equatorial climate is being taken over by a tropical climate. These changes possibly favour the immigration of $O$. ferruginea into western South America. At least here are climatic conditions at the locations in the Yunga similar to the main area of the species in the western Central America.

Possibly Pantala flavescens and Orthemis discolor take other ways of the immigration. The latter occurs in Peru predominantly east of the Andes in the equatorial climate zone and the changing tropical climate zones. $O$. discolor was, however, already recorded before 1936 in the northern and middle Chala, as well as after 1956 in the northern Yunga. The current records in Yunga and Quechua allow three options of dispersion: a longitudinal immigration from the northern distribution in the Yunga, a vertical dispersion from the Chala and thirdly immigration from its main distribution area east of the Andes. For an origin from the main distribution area speaks the fact, that $O$. discolor is stenoecious at the new locations, as it sometimes seems for some euryecious species at new settlements outside their eurytopic areas (Lattin 1967). This is not really to be expected with immigration from Chala and northern Yunga.

Pantala flavescens shows a similar dispersion pattern. The area of distribution of this species extends in South America up to the $20^{\circ} \mathrm{C}$ isotherms (annual mean temperature). Accordingly it occurs autochthony up to now only in the Chala and after 1998 also in the lower Yunga. Findings at high elevation sites of the Andes concerned exclusively migrating specimens. The current findings in the Yunga up to the Quechua 


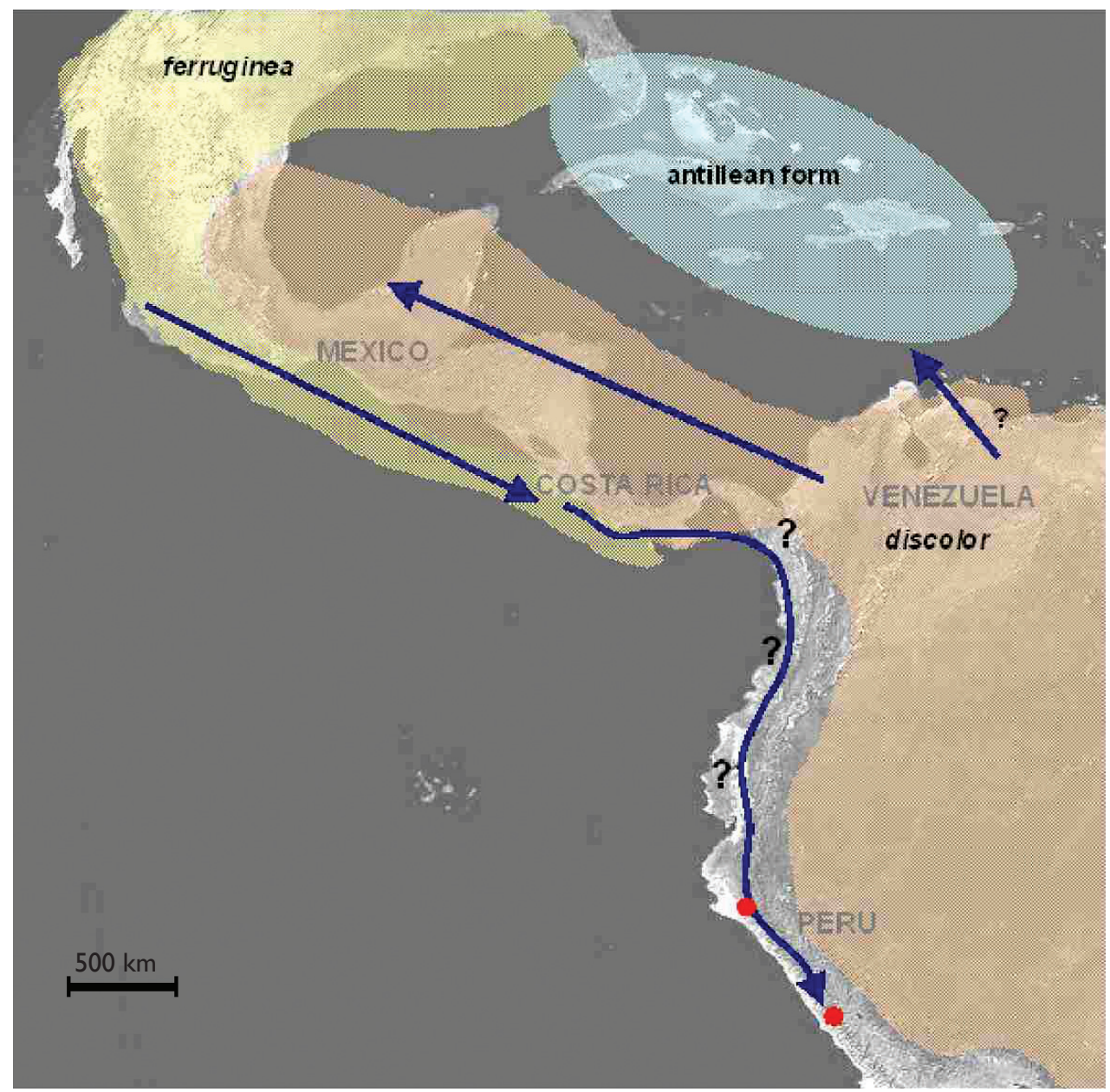

Figure 8. Distribution map of the Central American and Northwest South American regions of Orthemis ferruginea, $O$. discolor and the Antillean form. Arrows show the dispersion directions, question marks stand for open dispersal questions, the dots show the two places with records of $O$. ferruginea in the Peruvian Yunga.

at 2,800 $\mathrm{m}$ are from sheltered valleys (e.g. middle Santa and middle Pisco valley). The increase of the annual mean temperature, especially in higher altitudes was greater than the average for the whole country. Thus the annual mean for the temperature has increased in the Canyon del Pato from $18.6^{\circ} \mathrm{C}$ before 1980 to $19.7^{\circ} \mathrm{C}$ after 2000 (comm. of the data by Minera Huallanca S.A.C. 2006). Accordingly it must be supposed that the immigrations occur vertically. The species probably will be able to establish itself up within the next years up to the upper Quechua, particularly as it can reproduce successfully because it has a short larval development of three to five months (cf. Corbet 1999) and because of the formation and warming of some waters to more than $18^{\circ} \mathrm{C}$ (see above). 


\section{Conclusions and open questions}

The present data provide merely indications for the influence of the change of climate on dispersion and ecological adaptation of dragonflies to changing environmental conditions in the western Peruvian Andes. In most cases these data do not suffice for a statistical verification of the hypotheses.

Furthermore there is knowledge of only some few Anisoptera and also only in an area between $8^{\circ}$ and $14^{\circ}$ southern latitude. For rare species (as for example almost all gomphids) also, it will not be possible in future to collect the required data because of the necessary high personal financial expenditure and because of the extensive, mostly inaccessible area of approx. 200,000 kms ${ }^{2}$ in the western Peruvian Andes. Therefore, suitable investigations should concentrate in future also on a few groups and species but of redundance without losing sight of the requirement to compile an inventory. Furthermore it is nessecary to collect the data on the ecology of each species, since this is incompletely, known.

Whether and how climate changes in the western Peruvian Andes have an effect on the Zygoptera fauna, cannot at present be answered, because there are too few data and many species have not been even described up to now. Similar effects as described above can be expect. For example this may be shown by Protallagma titicacae and Ischnura capreola. Within the last few years, both species could be collected in nature regions from where there were no previous records. Furthermore, for both species adaptations to higher respectively lower temperatures are noticeable. To what extent drift through altered wind directions and wind forces are responsible (possibly these do influence also the dispersal behaviour of different Anisoptera), remains unanswered.

Changes in the UV radiation regime as a possible factor effecting the dispersal and diversity of dragonflies (and certainly also of other groups) should be taken into account in future and examined more closely.

During the last two study campaigns in August / September 2006 an Frebruary / March 2007 extremely high UV levels (UV-A and UV-B) could be measured primarily in the Puna at levels of more than $4,000 \mathrm{~m}$.

So the level was $15 \mathrm{UVI}$ at the lagoon Ututo $(4,464 \mathrm{~m}), 12 \mathrm{UVI}$ at the lagoon Querococha $(3,980 \mathrm{~m})$ and $14 \mathrm{UVI}$ at the lagoon Pumapashimin $(4,242 \mathrm{~m})$. These are extremely high values 5 which are accompanied by low atmospheric humidity (day averages $36 \%$ resp. $37 \%$ resp. $20 \%$ ). Conspicuous was that no dragonfly larvae could be found in any of these lagoons, while only several adult Rhionaeschna peralta flew in the shadows of the Polylepis stands (rosacean trees) near the lagoon Querococha. Especially UV-B radiation (wavelength $280-320 \mathrm{~nm}$ ) can also lead to considerable damage in insects - the smaller the wavelength the higher the energy and therefore the possibility of damage. Thus the genetic hereditary material is most sensitive to radiation of the above wavelengths (Tevini 1996). Studies on crustaceans which live just below the wa-

5 For comparison purposes: in the equatorial sea highland in Kenya maximum levels of 13 UVI were measured 
ter surface showed heavy damages and high rates of mortality at low-frequency UV-B radiation levels (Siebeck 1996).

Furthermore it cannot be excluded, that the imagines, which have a visual valence in the UV band, are impaired by changes of reflectivity. Thus may occur possible changes for the dragonflies originally visible species-specific colourings (Corbet in 1999) which could lead perhaps to irritations in the search for females and thus prevents matings. It is also conceivable that the colour of water surfaces and / or egglaying habitats (e.g. plants and plant groups) are differently perceived6.

Beside the inclusion of changed climate factors (wind and cloud cover included), it should be particularly important in future to examine the influence of UV radiation changes at high mountain levels.

The changed conditions considerably influence biotope and habitat structures and possibly also have an effect on the occurrence and the ecology of dragonflies in the western Peruvian Andes. Of the species discussed here, it can be suspected that the aeshnids react, with some few exceptions, predominantly to habitat losses, but probably are able to adapt flight times and reproduction times to the changed conditions. The libellulids seem to be much more flexible and appear to be able to conquer and colonize new areas and nature regions much more quickly, as well as to adapt flight times and reproductive times.

\section{References}

Arntz WE, Fahrbach E (1991) El Niño - Klimaexperiment der Natur. Birkhäuser, Basel, 264 pp. Beck Ch, Grieser J, Kottek M, Rubel F, Rudolf B (2006) Characterizing global climate change by means of Köppen climate classification. In: DWD (Ed) DWD - Klimastatusbericht 2005: 139-149. Offenbach, $191 \mathrm{pp}$.

Borror DJ (1942) A Revision of the Libelluline Genus Erythrodiplax (Odonata). - Contrib. Zool. a. Entomol. 4, Ohio State University, 286 pp.

Brack A (1985) Ecologia de un pais completo. In: La gran geografia del Peru: 177-319. Edit. Manfer-Mejia Baca, Tomo 2, pp.

Brack A (2000) Ecología del Peru. Asociación Editorial Bruño, Lima, 495 pp.

Busch-Nowak A (2002) Schlupf einer Libellula depressa im Oktober. Mercuriale Bd. 2, Schutzgemeinschaft Libellen in Baden-Württemberg e.V. (SGL)

Calvert PhP (1956) The neotropical species of the „subgebus Aeschna“ sensu Selysii 1883 (Odonata). - Mem. Am. ent. soc. 15, 1-251.

Caviedes CN (2001) El Niño in History: Storming through the Ages. University Press of Florida, $167 \mathrm{pp}$.

6 Insects can perceive UV; e.g. for humans equally blue tones are very well distinguished by bees if with one the UV proportion of the light is absorbed and with the other is reflected. The similar is valid with white and green tones (Dustmann and Geffcke 2000) 
CONAM (2001) Comunicación Nacional del Perú a la Convención Marco de las Naciones Unidas sobre Cambio Climático. http://www.conam.gob.pe/cambioclimatico/

Corbet PS (1999) Dragonflies, behaviour and ecology of Odonata. Harley Books, Colchester 1999, $829 \mathrm{pp}$.

Donnelly N (1995) Orthemis ferruginea - an adventure in Caribbean biogeography. Argia 7(4) 1995, 9-12.

Dustmann JF, Geffcken H (2000) Bienen können Farben unterscheiden. Nds. Inst. Bienenkunde Infom 13 (2000): 1-3.

El Congreso de la Repubblica de Perú (1994) Ley N² 28611 - Ley General del Ambiente. Editorial El Peruano 1994.

Ellenrieder N von (2003) A synopsis of the Neotropical species of 'Aeshna' Fabricius. The genus Rhionaeschna Förster (Odonata: Aeshnidae). Tijdschrift voor Entomologie 146(1): 67-207.

Förster F (1909) Beiträge zu den Gattungen und Arten der Libellen. Jahrbücher des Nassauischen Vereins für Naturkunde 62: 211-235.

Gellert-Grimm F (2005) Museum Wiesbaden Naturhistorische Landessammlung. Zoologie, Insekten, Odonata: Rhionaeschna maita Förster, 1909: 221. http://www.geller-grimm.de/ museum/samm024.html

Günther A (2005) Anax ephippiger in Europa - immer Invasionen in eine Sachgasse? (Odonata: Aeshnidae). Libellula 24 (3/4): 241-247.

Günther A (2006) Aeshna mixta Einflug in Sachsen und Brandenburg? GdO-Mailingliste 12/2006. In: Homepage der Gesellschaft deutschsprachiger Odonatologen (GdO), http:// www.libellula.org/

Hansen J, Ruedy R, Sato M, Lo K (2006) GISS Surface Temperature Analysis. Global Temperature Trends: 2005 Summation. NASA Goddard Institute for Space Studies and Columbia University Earth Institute, New York.

Heckman ChW (2006) Encyclopedia of South American Aquatic Insects: Odonata - Anisoptera. - Springer, Dordrecht, The Netherlands. 725 pp.

Hoess R (2006) Männchen von Coenagrion puella in Topzustand Ende Oktober in der Schweiz. GdO-Mailingliste 14/2006. In: Homepage der Gesellschaft deutschsprachiger Odonatologen (GdO), http://www.libellula.org/

Hoffmann J (1991) Distribution of the Aeshnids (Anisoptera) in the Peruvian Andes. Eleventh International of Odonatology, Trevi, Italy. Veröff. Mskr.: 17 pp.

Hoffmann J (1998) Pantala und der Taxifahrer. Hagenia 16: 17-19.

Hoffmann J (in prep) Projekttagebuch und erste Ergebnisse der 1. Kampagne des CCA-Projekts. IDF-Report.

Hoffmann J (2006) The CCA-Project. http://www.cca-world.eu/

Hoffmann J (2009) Summary Catalogue of the Odonata of Peru - kommentiertes Faksimile des Manuskripts von J. COWLEY, Cambridge, 20.05.1933 und aktuelle Liste der Odonaten Perus mit Fundortangaben sowie Historie zu Sammlern und Odonatologen in Peru. International Dragonfly Fund Report 16: 1-115.

Instituto Nacional de Geografía de Peru (1989) Atlas del Peru. Autoeditorial INGP, Lima, 389pp. 
Instituto Nacional de Geografía de Peru (1985) Mapa Ecologico del Peru. Autoeditorial INGP, Lima, 8 folders. Edit. Ignacio Mamani S., Lima, 221 pp.

Instituto Nacional de Recursos Naturales (1995) Mapa Ecologico del Peru. Guia Esplicativa. Köppen W (1972) Das geographische System der Klimate. Verlag Nendeln, Liechtenstein: Kraus-Reprint Originalausgabe Berlin 1936.

Kunz B (2006) Frühstart bei Sympetrum flaveolum. GdO-Mailingliste 05/2006. In: Homepage der Gesellschaft deutschsprachiger Odonatologen (GdO), http://www.libellula.org/

Lattin G de (1997) Grundriss der Zoogeographie. Gustav Fischer Verlag, Stuutgart, 602 pp.

NOAA (National Oceanic and Atmospheric Administration) (2005) NOAA's Seasonal Hurricane Outlooks Based on Two Tropical Climate Factors NOAA-Magazine 11/2005, Silver Spring.

Ott J (1996) Zeigt die Ausbreitung der Feuerlibelle Crocothemis erythraea BRULLÉ in Deutschland eine Klimaveränderung an? Naturschutz und Landschaftsplanung 2/96: 53-61.

Ott J (2000) Die Ausbreitung mediterraner Libellenarten in Deutschland und Europa - die Folge einer Klimaveränderung? NNA-Berichte 2/2000: 13-35.

Peters G, Günther A (2000) Frühjahrsbeobachtungen an Anax ephippiger auf Rhodos nebst Anmerkungen über den Invasionsraum der Art (Odonata: Aeshnidae). Libellula Supplement 3: 49-61.

Ris F (1913) Neuer Beitrag zur Kenntnis der Odonatenfauna von Argentina. Extrait des „Mémoires de la Société Entomologique de Belgique“, tome XXXII, 83 pp.

Schmidt E (1952) Odonata nebst Bemerkungen über die Anomisma und Chalcopteryx des Amazonas-Gebietes. Beiträge zur Fauna Perus Bd. II: 225-276.

Schönwiese C (1995) Klimaänderungen - Daten, Analysen, Prognosen. - Springer Verlag, Berlin Heidelberg.

SENAMHI (1998) Distribución climatica - Atlas.

SENHAMI (2006) 37 años al servicio de la meteorología en el país (1969-2006): proyectos y convenios. http://www.senamhi.gob.pe/

Siebeck O (1994) Impact of UV-B radiation on zooplankton and fish in pelagic freshwater ecosystems. Arch.Hydrobiol.Beih. Ergebn.Limnol. 43: 197-206.

Tevini M (1996) Erhöhte UV-B-Strahlung: ein Risiko für Nutzpflanzen. Biologie in unserer Zeit 4: 246-254.

Timmermann A, Bacher A, Latif M, Oberhuber JM, Roeckner E (1999) Increased El Niño Frequency in a climate model forced by future greenhouse warming. Nature, 398: 694-696.

UNESCO (2006) La cuenca del lago Titicaca. Bol. Sem. del Portal del Agua de la UNESCO $\mathrm{N}^{\circ} 135$ (Abril 2006): 21-35.

Woodman-Pollit R (1998) El Perú en los Albores del Siglo XXI/2. Ciclo de Conferencias 1997-1998”, Ediciones del Congreso del Perú, Lima-Perú, 1998: 201-242. 